\title{
GCU
}

Glasgow Caledonian

University

University for the Common Good

\section{The making and the portrayal of Scottish distinctiveness: how does the narrative} create its audience?

Nicolson, Marcus; Korkut, Umut

Published in:

International Migration

DOI:

10.1111/imig. 12944

Publication date:

2022

Document Version

Author accepted manuscript

Link to publication in ResearchOnline

Citation for published version (Harvard):

Nicolson, M \& Korkut, $U$ 2022, 'The making and the portrayal of Scottish distinctiveness: how does the narrative create its audience?', International Migration, vol. 60, no. 5, pp. 151-164. https://doi.org/10.1111/imig.12944

\section{General rights}

Copyright and moral rights for the publications made accessible in the public portal are retained by the authors and/or other copyright owners and it is a condition of accessing publications that users recognise and abide by the legal requirements associated with these rights.

Take down policy

If you believe that this document breaches copyright please view our takedown policy at https://edshare.gcu.ac.uk/id/eprint/5179 for details of how to contact us. 


\title{
The making and the portrayal of Scottish distinctiveness:
}

\section{How does the narrative create its audience?}

\begin{abstract}
How do states present themselves as inclusive towards migrants and their citizens? This article traces the discourse-to-audience framework through an analysis of the Scottish government's rhetoric on Scottish distinctiveness and its effect on how young migrants see Scotland. In order, we examine how the discourse of Scottish distinctiveness is constructed and conveyed through a close examination of Scottish First Minister Nicola Sturgeon's public speeches. Through the examples given we see how an image of Scotland as open, inclusive and outward-looking is invoked. We then examine how the discourse fosters its audiences through narrative interviews conducted with young adult migrants living in Scotland. We operationalise Foucault's theory of governmentality to this extent and argue that the macro narrative of distinctiveness directs the 'conduct of conduct' of young migrants in Scottish society.
\end{abstract}

Keywords: discursive; governance; governmentality; Scotland; immigration; nationalism; migration

\section{Introduction}

How do states present themselves as inclusive towards migrants and their citizens? What kind of identity-making is at play when states portray themselves to newcomers as inclusive and welcoming? Departing from these general questions, this article explores the Scottish context, built around the narrative of an 'open, inclusive and outward looking' Scotland. To this extent, we follow first how this narrative is constructed in political discourse and policy, how it is conveyed, and how it fosters its audiences. Theoretically, this paper is stimulated by seeking to understand the 
relationship between the macro-narrative and its micro-(re)interpretations. This is what we follow as the discourse-to-audience framework.

The Scottish government has long emphasised the nation's qualities as open, inclusive and outward looking (Davidson et. al. 2018) and its uniqueness. This has also entered into their political and policy discourse (Arnott and Ozga 2010, 2016; Moskal 2016). These discourses have gained traction within the wider public, particularly during the Scottish independence campaign in 2014. There has also been an element of presenting Scotland as more egalitarian with a greater concern for social welfare than the rest of the United Kingdom - particularly England (McCrone 2017; Davidson and Virdee 2018). One of the key elements of this narrative is a pro-immigration discursive stance that is also presented as distinct from the rest of the UK (Phipps and Fassetta 2015). This article focuses on the relationship between the macro-narrative of an inclusive Scotland and the experiences of newcomer migrant groups at the micro-level. Recent research has identified a "disjunction between pro-migration rhetoric and anti-immigration sentiments at population level” in Scotland (Sime 2020, 337). Despite the Scottish National Party (SNP) persistently describing Scotland as an open and welcoming place for migrants, there is evidence that Scotland is not so inclusive (McCrone and Bechoffer 2015; Bond 2017).

Survey findings have shown that a large proportion of the Scottish public do not support further immigration to Scotland. $37 \%$ of respondents to a YouGov poll taken in 2017 believed there were too many immigrants in Scotland, with another 40\% saying immigration was about right (Fraser 2019). This is further supported by a 2018 YouGov survey, which asked Scottish respondents if immigration to Britain over the past ten years has been too high, too low, or about right. 55\% of Scottish respondents stated that immigration has been too high similar to the findings from the London area (YouGov 
2018). For this article our focus is on how the SNP government follows a pro-migration discursive line in order to construct a Scottish distinctiveness within its audiences, thereby talking-up Scotland, and positioning Scotland as a more hospitable nation vis-a-vis the rest of the UK. This is operationalised through specific mechanisms which are employed to emphasize Scotland's self-defined favourable characteristics. Meanwhile, individuals that criticize Scotland's reputation are seen to be talking-down the country, which can result in their exclusion from the mainstream socio-political vision of Scotland. One manner in which we trace the Scottish distinctiveness narrative is through exploring the migrants' economic contribution discourse, which SNP politicians have foregrounded in discussions surrounding migration.

When the UK went to the polls in the Brexit referendum in 2016, a majority of Scottish voters (62\%) voted for the country to remain in the European Union. However, the majority British public voted to leave the EU and as such the UK has already left the EU. The SNP have adopted a strong anti-Brexit stance, which has also been used as a mechanism to portray Scotland's distinctiveness from England and other parts of the United Kingdom. In our analysis, we provide evidence of how the SNP's discursive strategies on Brexit have been used to support the 'open, welcoming and outwardlooking' Scotland narrative. We also explore the views of other leading Scottish politicians, from Scottish Labour and the Scottish Conservative and Unionist Party. This gives our study a greater overview of macro-level political discourse in the country.

Despite the claim that Scotland is unique, several international cases also illustrate that where a minority nation is attempting to attract migrants, they tend to present themselves as more open and more liberal than the majority component of the nation state. One can mention Quebec, South Tyrol and Catalunya as examples of this phenomenon. Medda-Windischer and Carla (2015) studied how South Tyrol presented 
itself as the forefront for migrant integration in Italy to highlight that the province was moving towards a greater degree of openness and diversity to guarantee civic citizenship for all. Studies on Quebec (Barker 2017; Blad and Couton 2009) explored how the province situated itself vis-à-vis the rest of Canada to emphasise its particular experience with migrants, and how nationalism and migration interrelate and accentuate each other to depict the province as open and multi-cultural. Finally, Catalonian authorities have used "residential citizenship" as a mechanism to promote their inclusion of migrants as a unique experience (Medda-Windischer and Carla eds. 2015). Consider these international experiences, our article indicates that an elaboration on migration narratives and experiences in Scotland can make a valuable contribution to scholarship on how and why minority nations may promote themselves as hospitable and open societies.

\section{Macro-Narratives and Micro (Re)Interpretations}

Oksala (2013: 40) argues that any analysis of power relations must recognize how power must be understood as constituting the subjects themselves. Governmentality is not a mere hegemonic state discourse, but rather an elaboration of subtler forms of power (Allen, 2011; Larner, 2003: 512). Said (1994) believed that state discourse can be thought of as an epistemological enforcer, which guides the population to specific mentalities. Scotland offers a "state in the making" context, which provides a more amenable environment to the enforcement of this epistemology. Lawler $(2014,72)$ has described governmentality as techniques of normalization, which have become the predominant means of government. We elaborate on the open, inclusive, and outward looking Scotland narrative to trace how the Scottish government conducts the conduct of being a member of the Scottish public. This involves a process of 'responsibilization' aligned with experiencing and embodying the narrative of open, inclusive, and outward-looking Scotland among its subjects. We follow this "responsibilization' narrative looking at the 
ways in which young adult migrants recount their experiences of the most mundane situations when living in Scotland.

The Scottish distinctiveness narrative encourages self-management among the Scottish public to retain modalities of governmentality. Reflecting on Korkut (2017), we argue that these modalities represent politically and socially condoned compartmentalized roles within wider Scottish society. These modalities can include support for the Scottish independence campaign (Botterill et al. 2016), endorsement of SNP policies (Botterill, Sanghera and Hopkins 2017), using Scottish signifiers in everyday appearance (Hopkins 2014), and adoption of a distinctive Scottish accent (Ryan 2018). These modalities also inform roles allocated to being a Scottish citizen, urging them to follow the macro-narrative of Scottish distinctiveness. However, this does not mean that the Scottish public endorses the SNP's macro-narrative of inclusive citizenship. For example, non-civic and exclusive criteria, including birthplace and ancestry, continue to determine public perceptions of national belonging and Scottishness (McCollum, Nowok, and Tindal 2014).

We argue that to make up for the disparity between the SNP's presentation of open Scotland as an element of Scottish distinctiveness and the general public perceptions of immigration that we presented above, the SNP emphasise migrants' economic benefit to Scotland. Our research finds that this could demand responsibilization from young adult migrants in Scotland in order to conduct their own conduct in everyday situations. This responsibilization incorporates two components. Firstly, it directs the wider society to adopt the Scottish distinctive narrative. Secondly, it encourages migrants in Scotland to incorporate the discourse in to their own lived-experience. That is how our interpretation of responsibilization in Foucauldian terms goes beyond the existing research in the field, which studies it as working through threats to personal control, 
insecurity and governance by fear (Pyssiäinen, Halpen, and Guilfoyle 2017). Hence, as we will depict below, young adult migrants in our study perform their politically condoned roles and identities in order to fulfil the SNP's vision for an independent Scotland. To contribute to Foucauldian research, we focus on a rationality of governance that produces new kinds of political subjects under the domination of a political narrative affecting all social practices (Oksala, 2013: 34). We follow how epistemologies of Scottishness distinctiveness foster the rationality around which migrants are welcome but how they should behave.

In order, we examine 'open, inclusive and outward-looking' as terms that are embedded in the Scottish political narrative, and their effect on how individuals should conduct themselves within the Scottish government's vision of an independent Scotland. This discourse implies an element of self-transformation, and virtuous acts to express a sense of a proper Scottish citizenship. It is designed to create a form of effective selfmanagement by making people interpret the narrative in a way that being Scottish and living in Scotland require. Eventually, this discourse encourages the idea of an active citizenship whereby people - including migrants - 'talk-up' Scotland in order to fit into the SNP-defined narrative of Scottish distinctiveness.

Foucault suggested that the 'conduct of conduct' focuses on the internal capacities of individuals and accompanies a form of societal governance (2008 [1979]). In a way, by circulating narratives of Scotland's 'distinctive inclusiveness', politicians aim to bolster nationalism and steer 'conduct of conduct' among those living in Scotland. It would appear that young adult migrants feel the need to order how they conduct themselves and subsequently become subjects that are eminently governable, and correlate of governmentality (Foucault, 2008 [1979]: 270-271). In the following sections, we will now trace how governmentality operates through first tracing an 'open, inclusive 
and outward-looking' Scotland as a political narrative, and then how it is constructed, conveyed, and it fosters its audiences. To this extent, we recognise that discursive practice as truth-producing practice is not always at the forefront of politics, but mostly in the background. Moreover, discourses construct the object of knowledge in such a way that they make only certain forthcoming interpretations and modes of reasoning possible. While political agents can construct discourses, discourses also speak through us, through our human agency, and thereby privilege and shape certain ways of apprehending the world (Korkut 2020). This is what we follow as discourse-to-audience framework throughout this article.

\section{Constructing an Open, Inclusive and Outward-Looking Scotland}

Both unionist (Scottish Labour, Scottish Liberal Democrats and the Scottish Conservative and Unionist Party) and nationalist political parties (SNP and Scottish Greens) in Scotland have long emphasised that Scotland is a welcoming and 'outward looking nation' and promoted a narrative of an inclusive civic nationalism (Leith 2012). The main voice of civic nationalism in Scotland, however, has been the Scottish National Party (SNP) (Mycock 2012). The SNP has been the dominant party in Scottish politics for over a decade. On $7^{\text {th }}$ May 2021 the SNP won 64 out of 129 available seats in the Scottish Parliament during the Scottish Parliament Election, falling just one seat short of an overall majority. It is the governing party in Scotland supported by the Scottish Greens in the Scottish Parliament. The SNP has long pursued its goal of Scottish independence from the United Kingdom. However, when the country went to the polls in 2014 the campaign failed to secure Scottish independence. Since the 2014 referendum, support for the SNP has increased notably and the party has been campaigning further for a second independence referendum.

The SNP argue in favour of higher levels of immigration for Scotland, an issue 
currently controlled by the UK government. However, in their discourse we also see that immigration is most commonly aligned with the economic contribution that migrants are perceived to offer. This pro-immigration stance is supported by public campaigns to promote a multicultural Scottish citizenship, including the 'We Are Scotland' campaign (Scottish Government 2020). Despite these initiatives and pro-migration politics of the SNP government, we can see that the Scottish public has a different view of the significance of the contribution that migrants of different nationalities make towards the economy. In a 2018 YouGov survey, more Scottish respondents believed that Nigerians, Somalians, and Romanians made a negative economic contribution towards life in Britain than positive (YouGov 2018). Furthermore, a YouGov survey conducted in February 2020 found that only 36\% Scots think that immigration has made a positive contribution to their local area (YouGov 2020). Survey evidence therefore discredits the Scottish government's larger inclusiveness narrative, and again emphasizes a disparity between the views of political elites and the majority population.

Moreover, behind the SNPs macro-narratives of inclusivity and tolerance, it is unclear what belonging to Scotland entails and to whom a Scottish identity is available (Sime 2020). Since the early 2000s, the SNP has supported civic nationalist interpretations of Scottishness, and formulated both its immigration policies and public discourse around the benefits of immigration. The Scottish government has led the 'Fresh Talent' (2004 - 2008) and 'One Scotland, Many Cultures’ (2002 - present) campaigns to highlight Scotland as a destination country for migrants. Furthermore, the Scottish Government's 'New Scots 2018-2022' framework has been developed with the objective of improving integration processes for asylum seeker and refugee arrivals in the country (Scottish Government 2018). As Scotland has a declining birth-rate, a priority for previous Scottish Governments and the current SNP administration has been to attract 
highly skilled migrants to Scotland to ensure economic prosperity for Scotland (Hepburn and Rosie 2014). However, despite the SNP's civic nationalist rhetoric, it has faced criticism for focusing on the economic contribution of migrants, overlooking other benefits, such as linguistic and cultural richness, which diversity would provide (Phipps and Fassetta 2015).

Scotland is personified in political discourse as a 'small, proud, welcoming, open and tolerant country', which has furthered civic nationalist sentiment (Bechhofer and McCrone 2009). However, despite politicians' best efforts to promote an inclusive civic nationalism, non-civic and exclusive criteria continue to influence public perceptions of national belonging and Scottishness (McCollum, Nowok and Tindal 2014). Liinpää (2018) has found that when migrants arrive in Scotland, they are more likely to accept positive narratives about Scotland's inclusiveness. Furthermore, in research with young adult migrants Gawlewitz (2020) identified a Scottish narrative of distinctiveness within which mythmaking about the nation's qualities of openness plays a central role. To make up for perceived visual differences, Hopkins (2014) has discovered that Young Sikhs living in urban areas in Scotland adhere to fixed markers of Scottish nationalism, including the wearing of the kilt and tartan clothing. This has become their way to emphasise their feelings of belonging to a nation state in the making, alongside their expressed political claims of belonging. Hopkins's findings reflect the importance of cultural markers and physically portraying one's national affiliations in Scotland. We believe that these elements can also be interpreted within the responsibilization process.

In contrast to existing research quoted above, our research follows micronarratives around lived-experiences in order to trace how the open, inclusive and outward-looking Scotland tropes affect how young migrants negotiate their identities in everyday Scotland. Therefore, we delineate identity negotiations of young migrants in 
mundane situations when they try to balance the demands of responsibilization and every day environments where they face hostilities. Their deliberations in micro-spheres for us present the real stories of social inclusion. Between 2019 and 2020, we interviewed five migrants with either residency or citizenship status in the UK living in Glasgow. The study participants were born in Czech Republic, Ghana, Nigeria and Somalia, and arrived in the UK as adolescents. There were two female participants and three males in the sample group. Participants were aged between 18 and 26 years old at the time of interview. Two of them identified as Muslim and three identified as Christian. The participants were recruited for a two-year long European research project called VOLPOWER. The interviews were conducted in a two-wave approach whereby participants were given the opportunity to revisit their earlier narrative with a year between.

These interviews were conducted for an international EU-funded project VOLPOWER and it followed the set ethical guidelines considering the researcher and participant safety. The recruitment process as well as the interview related information sheets, consent sheets and questions were all approved by Glasgow Caledonian University ethics board prior to commencing the research. We followed an inductive method informed by our theoretical and conceptual interest. We further analysed the interview texts using Nvivo software to establish trends within lengthy interview texts. In order to achieve a micro-, meso-, and macro-level analysis, we moved from interview texts with migrants (micro) to interviews with politicians (meso) and finally checked how certain themes we came across in the latter two levels of analysis were framed within the Scottish political discourse (macro). This process allowed us to explore how Foucauldian responsibilization was experienced, conveyed and constructed by real life experiences and narratives. While we cannot claim that our sample is representative, we certainly 
show that our interviewees' experiences are pertinent to understand young migrants' lives in Scotland. When selecting the political speeches, we read a wide array of speeches from 2014 to 2020 reaching almost 20. Out of them, we selected speeches as per their audiences i.e. domestic or international. Thereby, we present a representative scope of Sturgeon's narrative on Scotland and migration both at home and abroad.

The interviews asked participants for their experiences of life in Scotland and what made them feel included. Furthermore, we explored whether the young adult migrants had experienced discrimination and how they coped with instances of hostility. We also questioned what their experiences had been in other parts of the UK. Finally, we asked what characteristics one needs to call oneself Scottish. In order to understand the macro-narrative foundations that inform participant depictions of life in Scotland, we studied Nicola Sturgeon’s speeches to assess how open, inclusive, and outward looking Scotland is discursively constructed. Finally, we conducted interviews with MSPs Anas Sarwar, from the Scottish Labour Party, and Annie Wells, Scottish Conservative and Unionist Party. Below, we will discuss first how the macro-narrative of Scottish distinctiveness is constructed and conveyed and, second, how it fosters its audiences conducting their own conduct facing responsibilization that the macro-narrative demands.

\section{How is Discourse of Scottish Distinctiveness Constructed and Conveyed?}

In this section, we take examples of how the First Minister Nicola Sturgeon follows the 'open, inclusive, outward-looking Scotland' narrative in her speeches surrounding both immigration and Brexit. These examples are important, first, to highlight how migrants are portrayed in light of their economic contribution and, second, to present Scottish society as distinctively inclusive in comparison to the rest of the UK. The reason why this paper primarily focuses on First Minister's speeches is that 
immigration is a reserved matter for the UK Constitution. This means that while there are policies and recommendations (e.g. New Scots Integration Strategy 2018 - 2022), Scotland as a country does not have a right to determine its immigration policy. In Scotland, migration policy is therefore discursively governed and any legislation in effect has to align with the UK government. Ultimately, across the UK local authorities there are differences in terms of some integration measures directed to migrants.

In Scotland the New Scots Strategy (Scottish Government 2018) has the objective of integrating asylum seekers from day one without a requirement for asylum seekers to have acquired refugee status. Devolved governments and local authorities therefore have developed diverse approaches to addressing integration policy. Beyond Scotland, the Welsh Government released its integration strategy 'Nation of Sanctuary - Refugee and Asylum Seeker Plan' in 2019. There are also numerous sub-national integration strategies, for example the 'Mayor's Strategy for Social Integration' which covers London (2018), the 'Regional Integration Strategy for Refugees and Asylum Seekers in Yorkshire and Humber 2009-2011' (2009) and Peterborough's 'Community Cohesion Strategy’ (2012). However, our focus in this article is not reflective of the nuances and diversions in policy, but rather on the discursive practices of the Scottish government and its subsequent effects on young adult migrants. That is why in the section that follows we are going to look at First Minister Nicola Sturgeon's speeches, where she invokes a narrative of Scottish distinctiveness.

At a rally in November 2019 at Glasgow's George Square, Sturgeon stated that "the Scotland we seek is open, welcoming, diverse and inclusive and no Tory is ever going to be allowed to change that” (Guardian News 2019 at 15:00). Using signifiers as such, the SNP portrays Scotland as a welcoming country, but once we look further into her discourse, this open country also needs migrant's contribution. This shows the 
emphasis that Sturgeon puts on the economic advantage that migrants can bring to Scotland in her speeches. It is also a sign of the power of the First Minister embedded in macro political discourse to define the remit of a migrant in Scotland and the expectations that are put upon them. For us, this is a sign of how neo-liberal governmentality is operationalized. Below, we will look into responsibilization that comes with it as we read interviews with young adult migrants.

Later, in January 2020 at the launch of the proposed 'Scottish Visa' programme1, Sturgeon stated that migrants will be vital to sustaining the country's public services. Sturgeon continued “[...] these new Scots have made Scotland’s population younger something which is important to the sustainability of public services”. Hereby, the benefit of immigrants paying taxes appears to precede other considerations such as humanitarianism related to migration. Furthermore, what is crucial for our purposes is that she steers the public's perception of immigration into Scotland along an economic contribution narrative while she is branding Scotland as an open and welcoming place. Yet, as we will show in the next section, this also imposes a demand for responsibilization to talk Scotland up onto young adult migrants.

The next quotation taken from Nicola Sturgeon's speech at the SNP party conference in 2016 provides the substance for our argument. She describes inclusivity as a prerequisite for an independent Scotland where migrants contribute.

It begins with an 'I'. No, not that one! Not yet [in reference to independence] The word I want you to remember is this - inclusion. Inclusion is the guiding principle for everything we do. It encapsulates what we stand for as a party and it describes the kind of country, we want Scotland to be. A country where we value people for the contribution they make. Not one where we will ever judge them on their country 
of birth or the colour of their passport. That is the inclusive Scotland we are working to build. And I'm proud of the progress we've made (First Minister Nicola Sturgeon's Address to SNP Party Conference 2016).

In her speech, Sturgeon again references that Scotland is inclusive towards those who make a 'contribution', which follow as an economic contribution to the country. Furthermore, in a letter to EU citizens after the Brexit vote, Sturgeon appealed to EU citizens to remain in Scotland despite the impending exit from the European Union. Sturgeon emphasized this time migrant's contribution to Scotland's culture alongside their contribution to economy and public services.

[...] Scotland is your home, you are welcome here, and you are valued. You play a crucial role in Scotland's economy and public services. You are a vital part of Scotland not just for the skills and talent you bring to our country but also the diversity and richness you bring to our culture and communities. (First Minister Nicola Sturgeon's Letter to EU Citizens, April 5th, 2019)

We take this as further evidence of the contribution narrative that subsequently justifies migration. At the same time, knowing that this speech would go beyond the EU migrant population and reach the general Scottish public, we can see that this is another instrument of inculcating Scottish distinctiveness in the public domain. Moreover, while in her earlier speeches, Sturgeon was taking the Scottish public as her audience speaking about migration, this was the first time she took migrants, that is, mobile EU citizens, as her audience. This was also her acknowledgment that EU migrants could have agency in Scottish politics. Through this interpretation she infers, as quoted below, that it is Scotland that values diversity and inclusiveness whereas England does not. This statement becomes a means through which to consolidate EU migrants in Scotland as possible future supporters of Scottish independence. Sturgeon elaborates further on this same point as below taken from her statement on Brexit and Scotland's future. 
In Scotland, we know, we understand that the Westminster approach to migration as well as being deeply inhumane - poses an existential threat to our future prosperity. (Brexit and Scotland's future: First Minister Nicola Sturgeon’s statement April 24 ${ }^{\text {th }}$ 2019)

Again, the First Minister interlinks questions of curtailing migration to UK with economic precarity and the threat that both would impose on Scotland's future. In practice, it becomes the EU migrants' role to carry out the bulk of service industry jobs that support the Scottish economy (Scottish Government 2020). Scotland's qualities of fairness and welcoming characteristics are also invoked to underpin the country's further division from the 'Westminster' administration of the UK government. The issues of migration and economy are rarely separated in the SNP's discourse as we show above, and these examples illustrate how England's “inhumanity” is holding back Scotland from economic prosperity. These examples attest to Gawlewitz’ $(2020,9)$ finding that “...Brexit is reshaping how Scotland is narrated.”

Another discursive mechanism employed by the SNP to highlight Scotland's distinctiveness is through reference to European partnership, which Sturgeon frames to garner support for the independence movement. This is inferred through the use of “outward-looking” as a catch-all phrase to demark Scotland as pro-EU.

[...] for the Scottish Government, independence is not about the isolationism that characterises Brexit - instead independence would see us recognizing and embracing our interdependence with other nations. We will always seek to be close allies and partners with our neighbours in Europe. The last two years, to my mind, have underlined the importance of that position [in reference to the Brexit referendum in 2016] (First Minister Nicola Sturgeon’s Speech at French National Assembly Feb $\left.19^{\text {th }} 2019\right)$.

Scotland is part by tradition and practice an open and outward-looking country. And we're determined to remain an open and outward-looking country. We want to 
strengthen our international relations not move away from them (First Minister

Nicola Sturgeon's Speech at Made in Scotland Festival, Brussels, $11^{\text {th }}$ June 2019).

In the above two examples Sturgeon affirms what Brown et al. (1998) referred to as Scotland's 'modern and progressive outlook', which is represented through a pledge to remain a member of the European Union. Historically, however, the SNP has not always been a pro-EU political party. Until 1988, the party leadership opposed membership in the European Community "mirroring the public perception that the EC suffered from “euro-sclerosis” and inefficiency” (van der Zwet 2015: 168). Seeing the anti-European voice gaining traction in English politics, the SNP transformed its view on the EC to achieve its goal of independence in Europe (van der Zwet 2015: 168). This remains their position to date.

This shows that the SNP has been a pragmatic party on issues related to Europe, and this pragmatism often formulated against the UK governments' stance. Both Brexit and migration debates are examples of this. In the above example, particularly, the inferred image is one of a modern, progressive, and outward-looking Scotland. Sturgeon has gone further to promote the civic narrative of Scottish national identity in her vision of an independent Scotland. Moreover, she emphasised a comprehensive Scottish identity, which is not only at home in Europe but also congruent with Britishness as below. We noticed that she highlighted this when abroad but not in Scotland. This shows how the context affects her narration of the expanse of civic qualities of the Scottish national identity.

[...] for many people in Scotland - and I'm sure, across Europe - patriotism can be even more multifaceted. We can be Scottish and British and European. We can be Scottish and Polish - or Italian, or Pakistani, and much else besides - and European. [...] And so it shouldn't be surprising that belief in Scottish independence - which is about self-government, not about ethnicity - goes hand in hand with a strong belief in internationalism and interdependence. National identity is not, and never should 
be, an exclusive concept (First Minister Nicola Sturgeon's speech at the European

Policy Centre, Brussels, 12th June 2019).

Hepburn and Rosie (2014, 242) have highlighted how "elite discourse [...] presents immigrants as key players in an open, inclusive and multicultural Scottish nation”. In contrast, Kiely et al. (2005) have found that there is a marked divergence between elite political attitudes and those of the general population. The general population are more likely to qualify Scottish citizenship on the ground of ethnocentric criteria, including birthplace and ancestry (McCollum, Nowok and Tindal 2014). The aforementioned YouGov opinion polls could provide further evidence for this inclination (YouGov 2018; 2020). Moving on from this disparity between the political discourse of the SNP governing party, its leader, and the public's sentiment, in the next section we trace how the Scottish distinctiveness narrative and its related migration discourse foster their audiences. We operationalise this process through tracing the narratives of young adult migrants in Glasgow when they reflect on their everyday experiences.

\section{How Does the Discourse Foster Its Audiences?}

The empirical discussion above has introduced the macro-narrative that we reflect on in this section. Butler (2011) stated that only through relating to the 'other' we can construct our own identities. Hall and Du Gay (1996) found that the other presents a mirror on which we formulate our own self-identity through a process of abjection and the creation of a group of marginalised subjects. In a study on the integration strategies of Pakistani Muslims in Scotland Hussain and Miller $(2006,198)$ found that this ethnic group “[...] adopt Scottish identities, Scottish attitudes, Scottish nationalism and even some degree of Anglophobia [...] as tools of integration”. Anglophobia, therefore, can play a role in the integration strategies of migrant communities in Scotland. Furthermore, the relationship with England continues to play a significant role in Scottish national 
identity formations (Emejulu 2013). McCrone and Bechhofer (2015) found that the way people ascribe to a Scottish identity was through a justification constructed on the premise that 'I'm Scottish because I'm not English'. Thus, a comparison with England and 'the English' appears to carry a significant weight in Scottish identity constructions. To understand how young migrants in Scotland, that is, the other, strive to relate their identity to conform with what the majority expects from them, we look into the self-reflections of five young adult migrants both with non-UK and UK citizenship. We present excerpts from our interview data to illustrate how the macro-narrative becomes embodied in personal identity constructions which relate closely to feelings of belonging. This is where we trace how governmentality can bolster the Scottish distinctiveness narrative in a way to demand from young adult migrants to conduct their own conduct along the expectations of the wider society from them.

In our interview findings our participants made references to how Scotland differed, in a positive light, to other parts of the UK, including England, in its reception of migrants.

I think Scotland is a lot friendlier than the whole UK, I think that's my opinion. And from what I've learned from and what I've heard, Scotland in general, it's more, you know, more friendly than the UK. Yeah, but that's not to say (the) UK is bad, but I feel like Scotland is better [...] In Scotland, especially Glasgow you know, its welcoming for everyone to come, you know, because they need more people, you know, like know what a mean, they're very welcoming (Interview 1).

In the above example we see that the participant has incorporated the Scottish government's aforementioned contribution narrative to justify their feeling that migrants are welcome in Scotland. It is also inferred that Scotland is friendlier and more inclusive than other parts of the UK in a manner that appears to replicate Nicola Sturgeon's discourse quoted above. At the same time, the interviewee is not justifying their claim on 
personal experiences but rather on what they 'heard' and 'learnt'. Furthermore, our study interviewees also emphasised a strong sense of belonging to the Glasgow area, which they felt was an exceptionally receptive environment. We came across this as their incorporation of the "People Make Glasgow" trope that the Glasgow City Council has branded the city with to both internal and external audiences.

Yeah definitely people make Glasgow [...] I think just, I've grown up here I've lived here I've lived here for a while, people are genuinely nice, I think. It's more, it's kind of the Scottish culture to be nice towards other people (Interview 2).

Paradoxically, the same participant outlined the physical violence and racism they have experienced when attending high school in Glasgow.

When I used to go to school we used to fight a lot just because I was, you know, with a different colour and I was Roma or they was calling me Gypsy [...] We had fights just because I was a Gypsy, I couldn't walk out on Govanhill on a Vicky Road (Victoria Rd) without getting chased. There used to be boys from Gorbals called GABB, get all the black $\mathrm{b}^{* * * * * *}$ s, and they was coming to Govanhill, ye know, and chasing young boys and picking up fights. (Interview 2).

We interpret this suppression of negative experience as a manner of avoiding stigmatization, as well as responsibilization and conforming to the wider Scottish narrative of open, inclusive, and outward-looking. The disparity between the two statements above also shows how the interviewee attempts to conduct their own conduct to fulfil the expectations of the host country and replicate its inclusiveness narrative.

Over the past few years Glasgow City Council has branded the city with the 'People Make Glasgow’ motto on billboards across the city. One participant argued these signs made them feel included in the city.

As you can see on the streets, there's always signs that say People Make Glasgow. So there's a lot of positive things, and all these years (I've lived here), at least I've 
never got anyone calling me names or telling me I don't belong to this country. So, Glasgow, it is the people are very kind so you won't get any problems even if you (are) from different countries. Yeah, Europeans, Africans. Everyone is welcome, to this country yeah (Interview 3).

It's like kinda, People Make Glasgow is welcoming for everyone. This is what ah love about Glasgow. Glasgow is not for some people, it's for everyone. Like of course you get some bad people that don't like, y'know my colour and stuff, but most people are like absolutely nice, yeah ah love Glasgow, ah love Glasgow. (Interview 3)

Furthermore, this interviewee had also faced racist and discriminatory treatment from a bus driver when traveling around Glasgow.

My travelin', ah'm not gonna lie to you, it could be rough sometimes, y'know...some drivers they give you dislike... Like they give you hassle an' stuff. Like when ah'm tryin' to get a ticket an they're like 'no you have to pay more cos you're an adult'. Even when I was 16, cos I look older, they're like 'no you have to pay extra money'...I used to be on the bus, they called the police, then y'know the policeman verified my age and I would go on the bus. (Interview 3 )

[...] ah feel like drivers, they give more hassle to more like, coloured people. That what ah think, that's what ah think. But not all of them, just only some of them. It's good and bad, at the same time y'get nice drivers that won't even look at you sticky. (Interview 3)

Again, in their narrative our participant quickly asserts that their negative experience has not tarnished their overall view of Glasgow, Scotland or perceptions of Scottish people. As Botterill et al. (2016; 128) have highlighted, instances of racism in Scotland are often treated as mere “banter”. We interpret our interviewees’ suppression of discriminatory experiences as a concerted effort to abide by the positive narrative of Scotland and to live up to the expectations of the macro-narrative that also underpins power. That is what we follow as responsibilization when conduct of conduct becomes compelling. Thereafter, 
governmentality operates in a way that encourages migrants to conduct their conduct in a manner to talk up macro-narratives of Scottish distinctiveness. Conversely, to dwell on the negative aspects of Scottish life would be interpreted as 'talking-down' the country, and would leave migrants in Scotland outside of the power dynamic and excluded in a society with strong minority nationalist sentiment. The interviewees’ internalisation of Scotland's inclusiveness also prevents them from critically reflecting on their experiences. Moreover, they strive to live up to the expectations that the power, represented by macro-narratives of Scottish distinctiveness, demands from them.

When discussing the negotiation of their own identities' vis-a-vis Scottishness, our interviewees felt that physical appearance, and accent, are substantial barriers to claiming a Scottish identity. One participant said that an unjustified claim to Scottish nationality could result in offending the wider population.

I feel if I tell people I was Scottish, with like a Scottish accent, that's me embarrassing myself because I do not look Scottish or appear Scottish, I cannot claim to be Scottish. People would say 'why are you calling yourself Scottish?', you know, you're black, that's very offensive! [to them] People might not wanna say that. But I'm that kinda person, I'm very cautious of wherever I am, I wouldn't wanna identify as what I'm not. I have a Scottish passport [in reference to UK passport] but that doesn't necessarily make me Scottish, that just makes me someone like a resident in Scotland (Interview 4)

You can never call yourself Scottish because you are not from this country, and you claiming this country, is going to be too disrespectful to people that were actually born and raised in this country, you know? (Interview 4)

I don't have a Glasgow accent, so I think people think I'm a bit weird as well, they ask me where I'm from (Interview 1).

In the examples above, we see that that young adult migrants are reluctant to call themselves Scottish for several reasons. They are, however, bought in to the macro- 
narrative that depicts power and relegates their experiences of discrimination. The manner in which the interviewees deal with not having a local accent shows how they conduct their own conduct to meet the expectations of their host's power. Furthermore, our findings in this instance contradict the Scottish government's claim that a Scottish identity is available to all. Scottish identity remains most commonly constructed on ethno-centric criteria, including appearance.

The above example shows the power that the host society has to define who qualifies as Scottish affects the identity deliberations and coping strategies of young adult migrants. This is where we turn to Foucault and his theory of governmentality. As our research shows, the young adult migrants can be easily drawn in to the Scottish distinctiveness narrative. The participants experienced this narrative as a reflection of the host nation's power on them as a newcomer to Scotland. While they continuously deliberated with themselves why they were not good enough to be Scottish, they adopted the Scottish distinctiveness narrative to conceal what made them feel lacking certain characteristics such as accent and skin colour even if they are citizens in everyday life. They rationalised their experiences of racial discrimination on the grounds of being the perceived outsider, who does not have a right to call themselves Scottish. The manner in which they conducted their own conduct has been not to question Scotland's 'inclusive' qualities, but to promote positive interpretations of their everyday life to live up to the expectations of power.

\section{Conclusion}

This article has studied the relationship between macro-narratives of Scottish distinctiveness and micro-experiences of young adult migrants. We have presented our argument through a three-part process following how the Scottish distinctiveness 
narrative is constructed, conveyed, and how it fosters its audience. By invoking the audience to recognise key features of Scottish distinctiveness, namely, inclusive, welcoming and outward-looking, First Minister Nicola Sturgeon has depicted Scotland as distinct from the rest of the UK. To explain how the discourse waged an impact on her audience, we followed Foucauldian governmentality and the related conduct-of-conduct and responsibilization processes.

In conclusion, our article has three contributions. Firstly, our contribution to theory has found that governmentality is an all-encompassing process that makes young adult migrants receptive to discourse and responsible to power. Our interviewees follow a particular conduct of their own conduct to fulfil the expectations that the Scottish macronarrative of distinctiveness demands from them so much so that they disregard their negative experiences, including instances of racism. Secondly, this article is also of value to wider migration narrative studies as it illustrates how context and narrative shape the experiences and identities of young adult migrants. The study reflects how migration narratives are felt and replicated beyond the macro-level by foregrounding lived experiences. Finally, our findings present how in sub-state minority nationalist contexts, political discourse around migration can be used to bolster nationalist sentiment and qualify distinctiveness vis-à-vis the majority nation. In the Scottish context it appears that the economic contribution of migrants also justifies the Scottish government's proimmigration stance.

On $6^{\text {th }}$ May 2021 the SNP won yet another Scottish Parliament election with a promise of a new Scottish independence referendum. Over the coming years we are likely to see a further demarcation of Scotland as distinctive from the rest of the UK. All forms of nationalism rely on a construction of us versus them within which narrative and discursive practices will continue to play a significant role. We argue that we should not 
remain complacent in the face of the Scottish distinctiveness narrative. As Scottish Labour leader Anas Sarwar MSP states, "turn [your national] pride from being a reason not to act to a reason to act [...] to enable change rather than stopping debate.” The path that Scotland follows will not only define the future of the UK but also have ramifications for other minority nations and how they brand themselves globally. The issue of immigration is a particularly useful discursive mechanism to follow such trends.

\section{Data Availability Statement:}

The data that support the findings of this study are available from the corresponding author upon reasonable request.

\section{References:}

Allen, J. 2011. Lost Geographies of Power. Vol. 79 John Wiley \& Sons.

Bechhofer, F. and D. McCrone. 2009. "National Identity, Nationalism and Constitutional Change." In National Identity, Nationalism and Constitutional Change, 1-16: Springer.

Bond, R. 2017. "Multicultural Nationalism? National Identities among Minority Groups in Scotland's Census." Journal of Ethnic and Migration Studies 43 (7): 1121-1140. doi:10.1080/1369183X.2016.1232162.

Botterill, K, P. Hopkins, G. Sanghera, and R. Arshad. 2016. "Securing Disunion: Young People's Nationalism, Identities and (in) Securities in the Campaign for an Independent Scotland." Political Geography 55: 124-134. doi: 10.1016/j.polgeo.2016.09.002.

Botterill, K, G. Sanghera, G., and Hopkins, P. 2017. Young People: Muslim Youth in Scotland: Politics, Identity and Multicultural Citizenship Edinburgh University Press. doi:10.3366/edinburgh/9781474427234.003.0007. Brown, A, D. McCrone, L. Paterson and P. Surridge. 1998. The Scottish Electorate: The 1997 General Election and Beyond Springer.

Butler, J. 2011. Bodies that Matter: On the Discursive Limits of Sex Routledge. 
Davidson, N., M. Liinpää, M. McBride and S. Virdee. 2018. No Problem here: Understanding Racism in Scotland. Edinburgh: Luath Press Limited.

Davidson, N., and S. Virdee. 2018. Introduction: Understanding Racism in Scotland. Glasgow: Glasgow University Press

Emejulu, A. 2013. "Being and Belonging in Scotland: Exploring the Intersection of Ethnicity, Gender and National Identity among Scottish Pakistani Groups." Scottish Affairs 84 (1): 41-64. doi:10.3366/scot.2013.0027.

Foucault, M., [A. Davidson, and G. Burchell]. 2008. The Birth of Biopolitics: Lectures at the Collège De France, 1978-1979 Springer.

Foucault, M. 1979. Discipline and punish. Trans. A. Sheridan. New York: Vintage.

Fraser, D., 2019. “What is Scotland's attitude to immigration?” https://www.bbc.co.uk/news/uk$\underline{\text { scotland-scotland-business-50427399 }}$

Gawlewicz, A. 2020. "“Scotland’s Different”: Narratives of Scotland's Distinctiveness in the Post-Brexit-Vote Era." Scottish Affairs 29 (3). doi:10.3366/scot.2020.0326.

Guardian News. 2019. "Scottish first minister Nicola Sturgeon speaks at a pro-independence rally in Glasgow - watch live” (https://www.youtube.com/watch?v=Q1V-ty8gAuw Published $2^{\text {nd }}$ Nov 2019)

Hall, S., and P. Du Gay. 1996. Questions of Cultural Identity: SAGE Publications Sage. Hepburn, E. and M. Rosie. "Immigration, nationalism, and politics in Scotland." In The politics of immigration in multi-level states, pp. 241-260. Palgrave Macmillan, London, 2014.

Hopkins, P. 2014. "Managing Strangerhood: Young Sikh Men's Strategies." Environment and Planning A 46 (7): 1572-1585. doi:10.1068/a46263.

Hussain, A. M. and W.L. Miller. 2006. Multicultural Nationalism: Islamophobia, Anglophobia, and Devolution Oxford University Press on Demand.

Kiely, R., F. Bechhofer and D. McCrone. 2005. "Birth, Blood and Belonging: Identity Claims in Post-Devolution Scotland1." The Sociological Review 53 (1): 150-171. doi:10.1111/j.1467954X.2005.00507.x. 
Korkut, U. and Sarfati, Y., 2020. "The pious dissidence in Turkey: Contesting religious neoliberal governmentality under the AKP”. Politics, 40(4), pp.413-427.

Korkut, U. and Eslen-Ziya, H., 2017. "Politics and gender identity in Turkey: Centralised Islam for socio-economic control.” Routledge.

Larner, W. 2003. "Neoliberalism?" Environment and Planning D: Society and Space 21: 509512. doi:10.1068/d2105ed

Lawler, S. 2015. Identity: Sociological Perspectives John Wiley \& Sons.

Leith, M.S., 2012. Political discourse and national identity in Scotland. Edinburgh University Press.

Liinpää, M. 2018. "Nationalism from above and below: Interrogating race, ethnicity and belonging in post-devolutionary Scotland." PhD diss., University of Glasgow.

McCollum, D., B. Nowok, and S. Tindal. 2014. "Public Attitudes Towards Migration in Scotland: Exceptionality and Possible Policy Implications." Scottish Affairs 23 (1): 79-102. doi:10.3366/scot.2014.0006.

McCrone, D. 2017. The New Sociology of Scotland Sage.

McCrone, D., and F. Bechhofer. 2015. Understanding National Identity Cambridge University Press.

Moskal, M. 2016. "Spaces of Not Belonging: Inclusive Nationalism and Education in Scotland." Scottish Geographical Journal 132 (1): 85-102. doi:10.1080/14702541.2015.1084028

Mycock, A. 2012. "SNP, Identity and Citizenship: Re-Imagining State and Nation." National Identities 14 (1): 53-69. doi:10.1080/14608944.2012.657078.

Oksala, J. 2013. "Feminism and Neoliberal Governmentality." Foucault Studies: 32-53.

Phipps, A., and Fassetta, G., 2015. "A Critical Analysis of Language Policy in Scotland." European Journal of Language Policy 7 (1): 5-29. doi:10.22439/fs.v0i16.4116. Ryan, S. D. 2018. "Language, Migration and Identity at School: A Sociolinguistic Study with Polish Adolescents in Glasgow." PhD diss., University of Glasgow.

Said, E. W. 1994. Culture and Imperialism. Vintage. 
Scottish Government. 2020. “Non-UK Nationals in Scotland’s Workforce Report.” https://www.gov.scot/publications/non-uk-nationals-in-scotlands-workforce/ Scottish Government. 2019. "Made in Scotland festival: First Minister's speech.” https://www.gov.scot/publications/made-scotland-brussels-launch/ Scottish Government. 2019. "Brexit and Scotland’s Future: First Minister Statement.” https://www.gov.scot/publications/first-minister-statement-brexit-scotlands-future/ Scottish Government. 2019. "Brexit and beyond: where next for Scottish-EU relations - First Minister’s speech.” https://www.gov.scot/publications/fm-brexit-beyond-next-scottish-eurelations/

Scottish Government. 2019. “First Minister’s speech at French National Assembly.” https://www.gov.scot/publications/first-ministers-speech-at-french-national-assembly/ Scottish Government. 2019. "First Minister’s letter to EU citizens in Scotland.” https://www.gov.scot/publications/first-ministers-letter-to-eu-citizens-in-scotland/ Scottish National Party. 2019. "Stronger for Scotland - the SNP General Election Manifesto.", last modified 26 November, accessed 20 June, 2020, https://www.snp.org/general-election2019/.

Sime, D. 2020. "New Scots? Eastern European Young People's Feelings of Belonging and National Identity in Scotland Post-Brexit." Scottish Affairs 29 (3). doi:10.3366/scot.2020.0327. Van der Zwet, A. 2015. "Operationalising National Identity: The Cases of the Scottish National Party and Frisian National Party." Nations and Nationalism 21 (1): 62-82. doi:10.1111/nana.12091. YouGov. 2020. “Scottish independence: Yes leads by 53\% to 47\%.”, last modified 12 August, accessed 16 November, 2020, https://yougov.co.uk/topics/politics/articlesreports/2020/08/12/scottish-independence-yes-leads-53-47. YouGov. 2018. “Where the public stands on immigration.” Last modified 27 April 2018, accessed 16 November, 2020, https://yougov.co.uk/topics/politics/articlesreports/2018/04/27/where-public-stands-immigration 
